\title{
Worm Food: \\ Towards a Typology of Worm and Lice Disease-Descriptions in Graeco-Roman Narratives*
}

\author{
CHRISTOPHER B. ZEICHMANN \\ Emmanuel College at the University of Toronto
}

The most revolting and painful diseases attested in ancient literature were skolekosis (infestation of worms/maggots within the body) and phthiriasis (infestation of lice within the body). Beyond the infestation of invertebrates within and under one's flesh, symptoms commonly included ulceration of the bowels or genitals, immense physical pain, stench, flesh rot, and liquid discharges. We are led to believe this condition was incurable, since it is almost universally depicted as a terminal disease. More recent readers - both scholars and laypeople - frequently understand such narratives as references to an historical disease. These readings are not merely credulous acceptance of bizarre stories. Scholars often argue that ancient authors embellished mundane skin maladies such as scabies or naïvely assumed that the gods caused these illnesses. ${ }^{1}$

Against the prevailing explanation that a real illness was exaggerated or misattributed to deities, I will suggest that ancient writers understood these stories as part of a literary trope that could be drawn upon to horrify or otherwise astound their audience with the unspoken threat of divine prowess. This normative function is evident both in worms' function as monsters during antiquity and via comparison with medical literature of the period. Through this comparison, it will be

\footnotetext{
* I wish to offer my thanks to the anonymous reviewers who had helpful suggestions on improving this article. Thanks also to Dennis R. MacDonald, Maggie Froelich, and Katherine Veach for insights on an early draft of this paper.

${ }^{1}$ E.g., Africa 1982; Ashrafian 2005; Carney 1961; Hirschmann et al. 2004; Holzapfel 199697; Johnson 2007; Keaveney and Madden 1982; Kokkinos 2002; Litchfield 1998; Loebl 1998; Madariaga and Smith 2004; McSherry 1997; Retief and Cilliers 2005; Riddle 1984; Roncalli 1987. Note that most ancient writers do not use the medical terms transliterated as "phthiriasis" or "skolekosis," but tend to simply refer to worms or lice in their narratives.
} 
argued that, despite similarities, one should distinguish between four kinds of disease-descriptions appearing in ancient texts: literary-skolekosis, the lousy philosopher, medical-phthiriasis, and Semitic-language narratives of worm consumption. Each component of this fourfold typology served very different functions in ancient literature and likely developed semi-independently of one another. Academic attention is most often paid to narratives of literary-skolekosis, but scholars sometimes supplement them with reference to these other tropes in a move that conflates fairly distinct concepts. Though this paper will briefly examine the lousy philosopher and Semitic-language narratives of worm consumption, this article's focus will be primarily directed toward literary-skolekosis and medical-phthiriasis, as we will see that medical diagnostic concerns are incompatible with the mythic functions of literary-skolekosis. This article concludes with an appendix offering a provisional categorization of ancient texts and their place within this typology.

\section{Literary-Skolekosis and the Lousy Philosopher}

Herodotus attests the earliest surviving record of either phthiraisis or skolekosis. He writes about a Cyrenaean queen named Pheretime who died after her body became infested with worms. Herodotus - like most other writers on this topic would hardly characterize her as a "victim" of the disease. Though brief, his summary is worth quoting in full:

She died an evil death. She became full of worms while still living, since excessive vengeance by people incurs the gods' anger. Thus and so excessive was the punishment inflicted by Pheretime the wife of Battos on the people of Barce. (Histories 4.205)

Context is warranted: the queen's horrendous treatment of the people of Barce (Barca of modern Libya) warranted divine retribution in Herodotus' view, and he attributed the disease's cause accordingly. Of the fifteen unique narratives of death by either phthiriasis or skolekosis, twelve explicitly attribute the disease to divine punishment and it remains implicit in the remaining three, which note their particularly vile life or the justice of the punishment. ${ }^{2}$ The church father Papias'

\footnotetext{
${ }^{2}$ Explicitly attributed to divinity: Acts 12.23 (Agrippa I); Eusebius Ecclesiastical History 8.16.3-5 // Lactantius Death of the Persecutors 33 (Galerius); Herodotus Histories 4.205 (Pheretime); Josephus Antiquities of the Jews 17.168-173 // Jewish War 1.656-658 (Herod the Great); Josephus Jewish War 7.451-453 (Catullus); Josephus Against Apion 2.143-
} 
narrative of Judas Iscariot's death may have the most obviously moralizing intent, warning would-be defectors in nascent Christianity about the consequences of their actions:

But Judas wandered around the world as a prominent example of impiety. His flesh was so bloated that he couldn't go through where a chariot could easily do so - not even the massiveness of his head! For they say that his eyelids were so swollen that he couldn't see any light at all and that his eyes couldn't be seen even with a doctor's lens, because they were buried too deep from the surface. And his penis looked larger and more disgusting than all such members, but pus and worms flowed from each part of his body through him into his genitals, causing such alone to be brought through it with pain. And they say after many tortures and torments that he died on his own land. This land has been deserted due to its stench and is now uninhabited - why, even to this day no one can go past that place unless they remember to plug their nose! (Papias of Hierapolis Fragment 3; translation from Zeichmann 2010, 427)

In a similar vein, the Jewish historian Josephus basks in the irony of the Gentile writer Apion (who ridiculed Jews, claiming that circumcision was mutilation) losing his entire genitals to the Lord's will by the disease. 2 Maccabees, recounting the Hasmonaean revolt, revels in the evil Seleucid king Antiochus IV Epiphanes' grisly death despite his deathbed repentance. While a few authors allow that their subject's death may have resulted from natural forces, most writers are clear that a deity dispensed it as justice.

Commentators disagree on the historicity of these narratives. One approach has been to downplay divine intervention in these stories and argue that the narratives are more-or-less historically sound otherwise. Representative of this approach is an article by Arthur Keaveney and John A. Madden. They contend that "only in very rare cases did [ancient writers] attribute phthiriasis to the gods" and that the words phthiriasis and skolekosis denoted "two entirely distinct diseases."

144 (Apion); Memnon Fragments of the Greek Historians 434.2.4-5 (Satyrus); Papias Fragment 3 (Judas Iscariot); Pausanias Description of Greece 9.7.2-4 (Cassander); 2 Maccabees 9.5-28 (Antiochus IV); Tertullian To Scapula 3 (Claudius); Testament of Job passim (Job, but see below). I interpret the grammatical construction known as the "divine passive" as explicit heavenly action.

Implicitly attributed to divinity: Diodorus Siculus Historical Library 34.2.23 (Eunus); Lucian Alexander 59 (Alexander the false prophet); Plutarch Sulla 36 (Sulla). Omitted are throwaway references to the effect of "so-and-so also died this way" due to the absence of a narrative, unless the author depicts it as punishment.

${ }^{3}$ Keaveney and Madden 1982, 90, 95. 
Keaveney and Madden also imply that the origins of the diseases were different: phthiriasis was a real disease that infected people in the Mediterranean West, whereas skolekosis was a fictional sickness originating in the pens of Eastern Mediterranean writers who were mostly Jewish or Christian. They also suggest that narratives of skolekosis developed historically later and came to replace the Greek tradition of phthiriasis.

There is much to dispute with this approach. First, divine intervention is a central component in nearly all narratives of literary-skolekosis, despite Keaveney and Madden's assertion to the contrary. Moreover, early pagan writers like Lucian (Alexander 59) and Pausanias (Description of Greece 9.7.2) used skolekosis instead of phthiriasis, also calling into question Keaveney and Madden's trajectory of Eastern worms superseding the older Hellenistic tradition of lice. There is also reason to believe that ancient writers understood phthiriasis and skolekosis as equivalents. Ancient biology was not particularly precise as is evident in the fact that both Pliny the Elder and Galen confused worms and lice in unrelated contexts, casting doubt upon clear distinctions between the two in antiquity. ${ }^{4}$ The parallels between the Jewish Herod the Great's skolekosis in Josephus and the pagan Sulla's phthiriasis in Plutarch also suggest the diseases were not significantly differentiated in narrative literature.

\section{Josephus Antiquities of the Jews 17.168-173 Plutarch Sulla 36}

The bowels of Herod, a cruel client-

king, were ulcerated immediately before his death

His genitals disintegrated into worms

Physicians were unable to help

A clear liquid discharged from his feet

Herod sought refuge from his pain by immersion in water

Josephus condemns Herod for the brutality of his rule and attributes the justice of his death to the Jewish God
The bowels of Sulla, a cruel dictator, were ulcerated immediately before his death

His flesh disintegrated into lice The lice were impossible to rid Lice discharged from his body Sulla sought refuge from his pain by immersion in water Plutarch condemns Sulla for the brutality of his rule and finds his death just, implying the gods caused it

Despite Josephus' and Plutarch's disagreement on what bug festered under the character's skin, their narratives are similar enough to suggest they drew upon the

\footnotetext{
${ }^{4}$ Pliny Natural History 11.114; Galen Opera 7.187. Cf. Lucian Conversation with Cronus 26 , which uses the word $\varphi \theta \varepsilon i ́ p$ ("louse") in reference to fruit-eating worms.
} 
same trope. The examples of Herod the Great and Sulla are hardly exceptional; one could compare numerous other stories of literary-skolekosis and find extensive overlap.

The similarity between narratives of phthiriasis and skolekosis is thus far from superficial. But such parallels do not necessitate that one categorize all such bugrelated illnesses under a unified trope about the "death of evil men," as does Raymond Brown, as this approach is reductionistic in the opposite direction. ${ }^{5}$ First, the earliest attestation of the disease, queen Pheretime, renders this gendered language imprecise. Second, it is clear that worms and lice are not essential elements of the trope. For instance, Memnon's death of Satyrus (Fragments of the Greek Historians 434.2.4-5) and two instances that Josephus describes (Against Apion 2.13; Jewish War 7.451-453), in all other respects identical with narratives about skolekosis and phthiriasis, mention neither lice nor worms.

The third and most important objection to Brown's generalization is that several texts refer briefly to individuals who suffered phthiriasis but were not depicted as evil by the author. For instance, Diogenes Laertius informs us that Plato died in such a manner (Lives of Eminent Philosophers 3.40, 4.4). Of course, historically speaking, the cause of Plato's death was almost certainly not phthiriasis, since his student Aristotle has nothing to say on the matter, despite the fact that he is the earliest surviving source concerning lice-infested skin (History of Animals 5.31), albeit describing something akin to scabies in medical terms. Regardless, Diogenes is uninterested in using this narrative to impugn Plato: divine punishment, moralization, physical pain, humiliation, and genital disfigurement are completely absent from Diogenes' narrative and there is minimal interest in Plato's deformities resulting from the disease. Keaveney and Madden reasonably suggest that the "lousy philosopher" was a literary trope of its own, citing the similar cases of the learned men Callisthenes, Pherecydes, and Speusippus as supporting evidence. ${ }^{6}$

Most descriptions of literary-skolekosis, were nearly identical with respect to symptoms and narrative structure, though authors might deviate from the trope as they deemed appropriate. The examples of Pheretime and Judas quoted above are representative, but it may be helpful to outline other common features of literaryskolekosis. One gets a sense of the key features from the five most detailed narratives of the phenomenon, namely, Papias on Judas Iscariot (Fragment 3), Josephus on Herod the Great (Antiquities of the Jews 17.168-173), Eusebius on Galerius (Ecclesiastical History 8.16.3-5), Memnon on Satyrus (Fragments of the

\footnotetext{
${ }^{5}$ Brown 1994, 1409.

${ }^{6}$ See Pliny Natural History 7.52; Diogenes Laertius Lives of Eminent Philosophers 1.118, 3.40, 4.4; Plutarch Sulla 36.4; Aristotle History of Animals 5.31.
} 
Greek Historians 434.2.4-5), and Lucian on Alexander the false prophet (Alexander 59). These five examples are much longer than typical narratives of literaryskolekosis, which are often limited to a few lines or a throwaway sentence. Only elements attested in at least three of these paradigmatic stories and two shorter accounts will be considered major elements of literary-skolekosis here; qualified statements will indicate variance within the trope.

Generally speaking, literary-skolekosis is depicted as follows. Before suffering, the individual was generally a noble or royal male that committed a heinous crime, either some sort of intolerable impiety or unrepentant brutality against his subjects. The ethnic or religious status of the individual is often foreign, holding an antagonistic relationship with the author's own ethnos and thus the people/deity offended: the Christian historian Eusebius describes the death of the emperor Galerius - a Roman pagan persecuting Christians, Josephus questions the legitimacy of Herod's Judaism, Memnon of Heraclea recounts the cruelty of Satyrus towards his own people, etc. One or multiple deities brought the offender to justice by inflicting him with worms (sometimes lice) for his offenses, causing decomposition of the flesh. The individual sometimes becomes bloated, generally attributed to gluttony or dropsy; the victim suffers emaciation in some other narratives. Because a quick recovery fails to present itself, the individual contacts a physician who offers only superficial assistance. The disease continues to worsen as rot, worms, or an ulcer affects the genitals or bowels. An uncontrollable flow of liquid from either the private parts or the flesh of their whole body tends to follow; this is accompanied by a vivid description of either the immense pain the victim is experiencing or their disfigured body. An intolerable stench emanates from the victim, frequently leading to isolation from servants and family members. Their suffering culminates in an unmourned, cowardly, and sometimes even celebrated death.

Thus, at least two major type-scenes involving infestation of invertebrates in the flesh existed in ancient literature: that of the excruciating death brought about by divine punishment and that of the lousy philosopher. Despite the fact that the terms are not entirely precise, the former will be termed "literary-skolekosis" and the latter "the lousy philosopher." The former refers to moralizing descriptions of worm and lice infestation in narrative literature, whereas the latter refers to philosophers who suffer a disease with the similar symptom of lice-infestation, but without prolonged agony or any clear celebration of their death. Literary evidence for the lousy philosopher is poor, so it is difficult to outline a type-scene with the degree of depth that was provided for literary-skolekosis above. 


\section{Literary-Skolekosis and Medical Phthiriasis}

Scholars often discuss literary-skolekosis in tandem with medical literature from antiquity, a move that assumes ancient medical writers had encountered the disease described in narrative literature. This move is problematic not least because narratives of literary-skolekosis have little basis in history or medicine: 1) narratives regularly encourage readers to enjoy the subject's suffering (see especially 2 Maccabees 9.5-28 and Papias Fragment 3), a matter that cannot be said of medical literature, where physical pain does not appear to be a major symptom; 2) there are many instances where a person's death is attested in multiple sources and literary-skolekosis is a demonstrably late development in the tradition; ${ }^{7} 3$ ) most texts attribute these deaths to gods and have a conspicuous didactic function; 4) a polemical ethnic element undergirds narratives of literary-skolekosis; 5) symptoms of literary-skolekosis conflict directly in some sources: for instance, the emperor Galerius is described as bloated in one source and gaunt in another; ${ }^{8}$ 6) literary elements rarely include disinterested medical symptoms or analysis, instead devoting ample space to topics of morality and the diseased individual's infamy; and 7) most narratives are variations on the same literary elements. The intended effect of literary-skolekosis thus appears more consistent with normative claims about good and bad leadership than disinterested medical description.

Some scholars advocate a position between historical naïveté and minimalist skepticism, suggesting that phthiriasis and skolekosis were genuine diseases, contending that victims suffered from scabies, even though the individual died of other causes. ${ }^{9}$ Malcolm Davies and Jeyaraney Kathirithamby rightly reject this centrist conclusion, contending that "this compromise seems to end up with the worst of all worlds, since none of the relevant individuals is actually recorded as suffering from scabies but from a fatal disease which falls within a recognized framework." ${ }^{10}$ Ancient writers were well aware of scabies and similar diseases, which were already termed $\psi \omega ́ \rho \alpha$ and $\psi \omega \rho i ́ \alpha \sigma ı$. One could level a similar

${ }^{7}$ Contrast the death of Antiochus IV Epiphanes in Polybius History 31.9 // 1 Maccabees 6.1-13 // Josephus Antiquities of the Jews 12.354-359; cf. Allen 1997, 56-66. Contrast also the death of Sulla in Plutarch Sulla 36// Appian Civil Wars 1.104-105 // Arrian Anabasis 4.14.3. Contrast the death of Eunus in Poseidonios Fragments of the Greek Historians 87.108 // Diodorus Siculus Historical Library 34.2.23.

${ }^{8}$ Galerius is overweight in Eusebius Ecclesiastical History 8.16.3-5 and underweight in Lactantius Death of the Persecutors 33; beyond this, the narratives of Galerius' death are nearly identical, since Lactantius depends upon Eusebius for his story. Other common-butcontradictory symptoms include the victims' near-paralysis and constant convulsions.

${ }^{9}$ E.g., Africa 1982; Keaveney and Madden 1982; Riddle 1984.

${ }^{10}$ Kathirithamby 1986, 175. 
criticism against recent medical experts' anachronistic attribution of Herod the Great's death to "chronic renal failure complicated by Fournier gangrene." 11 Josephus unambiguously invoked divine intervention as the source of Herod's illness, and Josephus' narrative only makes sense with this aspect intact - the entire story falls apart without it. Yet, at the same time, there is a common discussion of worm and louse infestation within medical literature of antiquity. From here, we might acknowledge yet another literary trope: not only is there the lousy philosopher and literary-skolekosis, but also medical-phthiriasis. These tropes fall within genre confines: literary-skolekosis and lousy philosopher are found exclusively in narrative literature, and as one would expect, medical phthiriasis is attested in philosophical and medical writings. ${ }^{12}$

The extensive writings of ancient medical professionals on bug infestation bear little resemblance to the narratives of literary-skolekosis or the lousy philosopher, describing something entirely distinct. The differences are often obscured by scholars who argue for the historicity of literary-skolekosis and the lousy philosopher, paying scant attention to their lack of correspondence with medical literature. For instance, the encyclopedist Celsus referred to the presence of lice in the eyelashes, a description sharing no other symptoms with literary-skolekosis or the lousy philosopher, despite the claims of Keaveney and Madden..$^{13}$ This is surprising, since Celsus terms this non-fatal disease phthiriasis, a Latin translit-

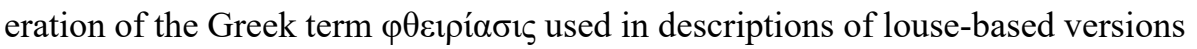

${ }^{11}$ Hirschmann et al. 2004, 836; see Josephus Antiquities of the Jews 17.168-173. Cf. modern medical diagnoses in Ashrafian 2005; Carney 1961; Holzapfel 1996-97; Johnson 2004; Litchfield 1998; Madariaga and Smith 2004; McSherry 1997; Retief and Cilliers 2005; Rabinovich 2004.

In a significantly different vein, Candida Moss 2019 draws upon Graeco-Roman moralizing literature to link bloating and gluttony with greed, contending that Papias depicts Judas Iscariot's sin as greed. Moss can only arrive at this conclusion by overlooking the moralizing within other depictions of literary-skolekosis.

12 The "origins" of this literary disease are unclear. If the reader is willing to grant voice to my own speculation, the fact that several instances of literary-skolekosis are demonstrably ekphrasis (see Zeichmann 2010) may indicate that it has its origin in an educational exercise, perhaps an assignment to describe the wound of Philoctetes (see, e.g., Quintus Smyrnaeus Posthomerica 9.383-432). Philoctetes figured into writing assignments in Greek education; an ostracon published in Milne 1908, 128 is a very rudimentary exercise on Philoctetes that misspells the hero's name, abruptly shifts tenses, and features several grammatical mistakes. Philoctetes also appears in several Greek grammars: Hellanicus Fragments of the Grammar 5; Apollodorus Fragment 173; Aristophanes Argumenta fabularum Aristophani tributa Fragment 2.10; Julius Pollux Onomasticon 4.117.4, 7.134.8; Aristonicus Critical Signs of the Iliad 2.718.1, 2.718.3, 2.721.2, 2.722.1, 2.724-725.2, 2.724.3; Aristonicus Critical Signs of the Odyssey 5.13.3.

${ }^{13}$ Contra Keaveney and Madden 1982, 88; see Celsus On Medicine 6.6.15-20. 
of literary-skolekosis and the lousy philosopher. The terminological overlap with narrative literature is significant, one might have expected Celsus to describe symptoms similar to literary-skolekosis or the lousy philosopher, but the resemblance is minimal. It is also surprising that even though literary-skolekosis often depicts doctors as attempting to remedy the disease through full-body immersion and physical removal of the bugs, surviving medical literature from antiquity never suggests either. In medical literature, the suggestions are only that one consume radish-juice (Pliny the Elder Natural History 19.26) and apply alkaloids externally (Galen Opera 12.462-463), neither of which are present in any depictions of literary-skolekosis. All of this suggests that the medical tradition of phthiriasis developed independently of narrative literature (i.e., literary-skolekosis and the lousy philosopher).

Another ancient medical expert, Soranus of Ephesus, offers only one additional parallel to symptoms in literary-skolekosis, "an erection of the penis during evacuation of the bowels" when lice infest the spleen (apud Caelius Aurelianus On Acute and Chronic Diseases 3.4.52; trans. Drabkin 1950: 743). While it is medically implausible that irritation of the spleen caused sexual arousal, Soranus' claim is nonetheless understandable in the context of Greco-Roman anthropology, since the spleen was associated with civility and decorum. As with other medical writers, Soranus' description of louse infestation has little in common with literary-skolekosis. However, when Soranus writes about the disease he terms $\sigma \kappa \omega \lambda \eta ் \omega \sigma \iota \varsigma$ (Latin: skolekosis), his description contains extensive parallels to the narrative trope, which in turn suggests he was dependent on narrative literature featuring literary-skolekosis. ${ }^{14}$ Correspondences between Soranus' medical skolekosis and the trope of literary-skolekosis include worms, emaciation, loss of bodily fluids, incontinence, evacuation of worms via defecation, ulceration of intestines, mania, explosion of intestines, and eventual death. The final three parallels between Soranus' medical description and literary-skolekosis are the most telling; mania's association with divine punishment is well known (cf. its use in Josephus Jewish War 7.451-453), the explosion of the abdominal region is medically incredible, and the remarkable odds of fatality would be expected of someone familiar with literary-skolekosis. Indeed, Soranus' medical treatise reads like a medically-minded reiteration of literary-skolekosis, couching each fantastical element of the trope in the more reputable language of medical diagnosis. One can repeat this assessment to a lesser extent about the writings of the Roman surgeon Galen, who offers a few fleeting references to phthiriasis that indicate a similar acquaintance with the unrealistic claims of narrative literature. ${ }^{15}$

\footnotetext{
${ }^{14}$ Apud Caelius Aurelianus On Acute and Chronic Diseases 4.8.106-130.

${ }^{15}$ E.g., Galen Opera 2.340, 7.187.
} 
Beyond these, the only disease whose symptoms resemble those of literaryskolekosis or the lousy philosopher in medical literature is phthisis. Phthisis is described as a flesh-rot typified by ulceration, incontinence, decomposition of flesh, emaciation, odorous phlegm, and loss of bodily fluids. Soranus notes that almost none of the physicians preceding him commented on this disease, suggesting that Soranus may have misinterpreted some sources on the similarly-named phthiriasis. ${ }^{16} \varphi \theta \varepsilon i \rho \omega$, a verb meaning "decay," would be a reasonable interpretation and source of confusion for ancient writers because of its resemblance to the Greek word for "louse," $\varphi \theta \varepsilon i ́ p$. One has difficulty discerning whether this mix-up resulted from intentional wordplay or mere confusion. In either case, this might explain why lice in particular were associated with these sorts of painful deaths.

\section{The Gods in Literary-Skolekosis and Semitic Narratives of Worm Consumption}

Whereas lice are portrayed as mere nuisances in other contexts, worms played a more devious role in ancient literature. These creatures are attracted to wounds, but they primarily evoke the gruesome image of corpse-consumption. ${ }^{17}$ Worms often functioned as shorthand for the horrific images of postmortem decay and its indignity, as they still do today. Ian Beavis observes that worms had a unique relationship with the gods in classical literature. ${ }^{18}$ Beavis notes several ancient writers who claim that all adult forms of worms ( $\mu$ ĩ $\alpha$; a species of fly) departed the city during the Olympic festival out of respect for the gods. These bugs were aware of the incompatibility between death (upon which they feed) and the celebratory presence of the gods. The reason for worms' literary association with death becomes clearer: worms could function as symbols of divine abandonment. The sufferers of literary-skolekosis, mostly comprising foreign royalty, retained emotional, political, physical, and social distance from their victims. The implicit abandonment of divine beings in literary-skolekosis functioned as retribution in cases where one lacked proximity to their enemies.

A fourth cousin to these three type-scenes (literary-skolekosis, the lousy philosopher, and medical-phthiriasis) existed as well, though the connection may be distant; these other narratives are found primarily in Semitic-language literature

${ }^{16}$ Caelius Aurelianus On Acute and Chronic Diseases 2.14.213. Soranus claims that Diocles is the sole exception to this rule; cf. the wormless and louseless stories noted above.

${ }^{17}$ On wounds, e.g., Theophrastus Characters 25. On corpse consumption, e.g., Herodotus Histories 3.16.4; Aristophanes Knights 1308; Homer Iliad 2.19-27.

${ }^{18}$ Beavis 1988, 225. 
and have substantial divergences from the type-scenes already discussed. ${ }^{19}$ Such Semitic-language stories, while sometimes involving a deity causing explosions of worms or abdomens to make a moral point, differ in most other ways from literary-skolekosis. First, the ethnicity of the sufferer in the Semitic-language schema was usually the same as the author's. Moses' disloyal men suffer from a wormy affliction in Pseudo-Jonathan's Targum on Numbers, a woman bursts when insulting another Israelite in the Talmudic tractate Nedarim, and Nadan both betrays and slanders his uncle Ahiqar in the latter's eponymous text. Some Semitic curse texts or visions may depict an ethnic-other as subject to the punishment, but these are not historical-narrative descriptions (e.g., Judith 16.17, Apocalypse of Peter 27). Second, the suffering of these victims lasts briefly, unless the worms arrive post-mortem as in Apocalypse of Peter and perhaps Pseudo-Jonathan's Targum. Regardless, agony and decomposition of flesh preceding death receives no special emphasis in these texts. Third, there is a relative lack of unity in comparison to the earlier examples; while stories of literary-skolekosis were similar in their structure and details, this is not the case in Semitic-language examples. People spontaneously burst, tongues infested with worms hang down to people's navels, and other features as extraordinary as those described in narratives of literary-skolekosis pervade these stories with little consistency. Rather than dismiss the parallels between skolekosis and these alternate deaths as irrelevant, it seems likely that they bore some influence on individual narratives of skolekosis (or vice versa, in some instances). ${ }^{20}$

Though initially appearing to straddle the tropes of literary-skolekosis and Semitic-language worm deaths, the Testament of Job actually works as the exception that confirms the rule. The Testament of Job depicts the titular character clearly within the confines of skolekosis, drawing upon the incidental imagery of worms in the biblical book about the same character (Job 17.14; 24.20; 25.6). That is, Job is a Gentile who falls from his noble status by the will of God for impiety

${ }^{19}$ E.g., Judith 16.17; Job 7.5 and passim; Ahiqar 8.38 (Arabic text); Babylonian Talmud Nedarim 50b; Mishnah Sotah 35.1 // Targum of Pseudo-Jonathan in Numbers 14.33; Apocalypse of Peter 27. For examples after classical antiquity, see Bondeson 1998; Busvine 1976, 195-203.

${ }^{20}$ A prime candidate for this influence is the Arabic version of Ahiqar (8.38) upon Papias' death of Judas Iscariot (Fragment 3). The Ahiqar text which involves a man named Nadan plotting to have his social superior Ahiqar executed for treason. Though Ahiqar is arrested and condemned to death, Nadan's scheme fails when Ahiqar is set free. The similarities to the story of Judas' betrayal of Jesus (as told by Papias) continue when Nadan swells and bursts as a divine punishment for his flagrant transgression of his benevolent superior's honor. Any study of Ahiqar's relevance to Papias' death of Judas will be fraught with complications, because the text of Ahiqar survives in recensions that deviate at important points. 
(Testament of Job 1.4-12); his flesh becomes moist, malodorous, sore, and infested with worms for several years (5.6-9), all while he sits in solitude. But despite these resemblances to literary-skolekosis, there are significant deviations from the trope: Job's impiety is accidental (2.9), he treats his citizens well (3.1), never succumbs to doubt (6.19), is eventually healed (11.19), and it is Satan who demands the punishment out of petty spite (4.12). Most importantly, the Testament of Job lacks a single summary of Job's sufferings, limiting the schadenfreude that readers may experience from the story. The Testament of Job's divergences from the standard narrative of literary-skolekosis contest the theodicy underlying the dominant narrative of literary-skolekosis, by retooling the causes and emotional effects of its symptoms; whereas the source of the punishment was unambiguously divine in most instances of literary-skolekosis, Job's story rejects a correlation between well-being and faithfulness to the divine. The Testament of Job presupposes, criticizes, and nuances the topos of literary-skolekosis in the very same way it does the biblical tale of Job.

While worms were not monsters in any cryptozoological sense, they almost uniformly inspire a feeling of dread consistent with Timothy Beal's concept of the Unheimlich in literary-skolekosis. ${ }^{21}$ Authors assure their readers that while the gods do not always protect the just, they will punish the cruel. Authors made recourse to holy - and subsequently unholy - action that ultimately engendered horror, suffering, desperation, and humiliation appropriate to the tyrannical transgressions. These social elites, among the few with unhindered access to medical professionals, found their typical means of bodily restoration utterly ineffective. Their pain was inescapable, connivances were fruitless, and efforts at reconciliation with their victims or the gods were futile. Most importantly, the elements that render worms monstrous within this trope (i.e., their alien, unholy, inextricable, painful, and deadly nature) apply equally to the portrayal of these rulers; the diseased are no less monstrous than the creatures eating their living flesh. The normative function of these stories is obvious: if one is a poor leader - harming one's subjects and offending the gods - one risks a horrific punishment.

Literary-skolekosis therefore functioned as shorthand for divine punishment, regardless of whether the exact disease depicted was worm-based (skolekosis) or louse-based (phthiriasis). Though some scholars contend that ancient writings contain authentic - if exaggerated - reminiscences about sufferings from the ancient world, narrative accounts and overlooked medical writings from antiquity preclude this option as a serious possibility. Verification comes most clearly when comparing the writings of ancient medics, which do not parallel narratives of

${ }^{21}$ Beal 2002, 4-6. Late in the writing process my attention was drawn to Solevåg 2018, $117-$ 132 , which argues a similar point. 
literary-skolekosis in matters of routine symptom and cure, despite the extensive overlap in fantastical sections.

\section{Appendix: Categorization of Relevant Texts}

This appendix provides the database for the foregoing analysis, gesturing toward a comprehensive list of Mediterranean texts featuring disease-descriptions involving subdermal worm or lice infestation. Citations are limited to the earliest known reference to the individual's death in such a way or other particularly famous discussions of this death.

\section{Literary-Skolekosis}

Agrippa I (Acts of the Apostles 12.23); Galerius (Eusebius Ecclesiastical History 8.16.3-5 // Lactantius Death of the Persecutors 33); Pheretime (Herodotus Histories 4.205); Herod the Great (Josephus Antiquities of the Jews 17.168-173// Jewish War 1.656-658); Catullus (Josephus Jewish War 7.451-453); Apion (Josephus Against Apion 2.143-144); Satyrus (Memnon Fragments of the Greek Historians 434.2.4-5); Judas Iscariot (Papias Fragment 3); Cassander (Pausanias Description of Greece 9.7.2-4); Antiochus IV Epiphanes (2 Maccabees 9.5-28); Claudius (Tertullian To Scapula 3); Eunus (Diodorus Siculus Historical Library 34.2.23 // Plutarch Sulla 36); Alexander the false prophet (Lucian Alexander 59); Sulla (Plutarch Sulla 36). Cf. Job (Testament of Job passim); Caelius Aurelianus On Acute and Chronic Diseases 2.14.213, 4.8.106-130; Galen Opera 2.340, 7.187 .

\section{Lousy Philosopher}

Plato (Diogenes Laertius Lives of Eminent Philosophers 3.40); Speusippus (Diogenes Laertius Lives of Eminent Philosophers 4.3-4); Pherecydes (Plutarch Sulla 36); Mucius Scaevola (Plutarch Sulla 36); Alcman (Plutarch Sulla 36); Acastus son of Pelias (Plutarch Sulla 36); Callisthenes (Plutarch Sulla 36).

\section{Medical Phthiriasis}

Aristotle History of Animals 5.31; Celsus On Medicine 6.6.15-20; Caelius Aurelianus On Acute and Chronic Diseases 4.8.106-130; Pliny the Elder Natural History 19.26; Galen Opera 12.462-463. 


\section{Semitic-Language Narratives of Worm Consumption}

Judith 16.17; Job 7.5 and passim; Ahiqar 8.38 (Arabic text); Babylonian Talmud Nedarim 50b; Mishnah Sotah 35.1 // Targum of Pseudo-Jonathan in Numbers 14.33; Apocalypse of Peter 27; Acts of Andrew (apud Gregory of Tours Liber de Miraculis Beati Andreae 33).

\section{Bibliography}

Africa, Thomas. 1982. "Worms and the Death of Kings: A Cautionary Note on Disease and History," Classical Antiquity 1, 1-17.

Ashrafian, H. 2005. "Herod the Great and His Worms," Journal of Infection 51, 82-83.

Allen, O. Wesley, Jr. 1997. The Death of Herod: The Narrative and Theological Function of Retribution in Luke-Acts, Atlanta: Scholars.

Beal, Timothy K. 2002. Religion and Its Monsters, New York: Routledge.

Beavis, Ian C. 1988. Insects and Other Invertebrates in Classical Antiquity, Alden: Oxford.

Bondeson, Jan. 1998. "Phthiriasis: The Riddle of the Lousy Disease," Journal of the Royal Society of Medicine 91, 228-334.

Brown, Raymond E. 1994. The Death of the Messiah: From Gethsemane to the Grave. A Commentary on the Passion Narratives in the Four Gospels, New York: Doubleday.

Busvine, J. P. 1976. Insects, Hygiene, and History: The Biology and Control of Insect Pests of Medical and Domestic Importance, London: Athlone.

Carney, T. F. 1961. "The Death of Sulla," Acta Classica 4, 64-79.

Davies, Malcolm and Jeyaraney Kathirithamby. 1986. Greek Insects, London: Duckworth.

Drabkin, I. E. (ed.) 1950. Caelius Aurelianus, On Acute Diseases and On Chronic Diseases, Chicago: University of Chicago Press.

Hirschmann, Jan V., Peter Richardson, Ross S. Kraemer, and Philip A. Mackowiak. 2004. "Death of an Arabian Jew," Archives of Internal Medicine 164, 833-839.

Holzapfel, R. N. 1996-97. "King Herod," Brigham Young University Studies 36, 35-73.

Johnson, Sindhu R. 2004. "Herod the Great and Polyarteritis Nodosa," Archives of Internal Medicine 164, 2508.

Keaveney, Arthur and John A. Madden. 1982. "Phthiriasis and Its Victims," Symbolae Osloenses 57, 87-99.

Kokkinos, Nikos. 2002. "Herod's Horrid Death," Biblical Archaeology Review 28/2, 28-31, $34-35,62$.

Litchfield, W. Reid. 1998. "The Bittersweet Demise of Herod the Great," Journal of the Royal Society of Medicine 91, 283-284.

Loebl, Walter Y. 1998. "The Bittersweet Demise of Herod the Great," Journal of the Royal Society of Medicine 91, 400.

Madariaga, Miguel G. and Philip W. Smith. 2004. "Infectious Disease Consultation for Herod the Great," Archives of Internal Medicine 164, 2507-2508.

McSherry, James. 1997. "Worms, Diabetes and King Herod the Great," Journal of Medical Biography 5, 167-169.

Milne, J. Grafton. 1908. "Relics of Graeco-Egyptian Schools," Journal of Hellenic Studies 28, 121-132. 
Moss, Candida R. 2019. “A Note on the Death of Judas in Papias,” New Testament Studies 65, 388-397.

Rabinovich, Ye. G. 2005. "The Lousy Disease: Sulla's Death in the Biographical Tradition," Journal of Ancient History 4, 21-39.

Retief, Francois P. and Johan F. G. Cilliers. 2005. "The Illnesses of Herod the Great," Acta Theologica Supplementum 7, 278-293.

Riddle, John M. 1984. "Gargilius Martialis as a Medical Writer," Journal of the History of Medicine 39, 408-429.

Roncalli, R. A. 1987. "The History of Scabies in Veterinary and Human Medicine from Biblical to Modern Times," Veterinary Parasitology 25, 193-198.

Solevåg, Anna Rebecca. 2018. Negotiating the Disabled Body: Representations of Disability in Early Christian Texts, Atlanta: Society of Biblical Literature.

Zeichmann, Christopher B. 2010. "Papias as Rhetorician: Ekphrasis in the Bishop's Account of Judas' Death," New Testament Studies 56, 427-429. 